\title{
АНТИОКСИДАНТНА ТЕРАПІЯ У ЖІНОК ІЗ БЕЗПЛІДДЯМ НА ФОНІ ЕНДОМЕТРІОЗУ
}

\author{
1ДВНЗ «Тернопільський державний медичний університет імені І. Я. Горбачевського МОЗ України», \\ м. Тернопіль, Україна \\ ${ }^{2}$ Медичний центр «Клініка професора С. Хміля», м. Тернопіль, Україна
}

\begin{abstract}
Мета: підвищити результативність протоколів допоміжних репродуктивних технологій 3 використанням комплексної прегравідарної терапії у жінок із безпліддям на фроні генітального ендометріозу.

Матеріали і методи. Рандомізоване клініко-лабораторне дослідження було проведено серед 104 пацієнток репродуктивного віку 3 безпліддям та гістологічно підтвердженим діагнозом генітального ендометріозу. Лікування безпліддя всім пацієнткам було проведено із застосуванням допоміжних репродуктивних технологій екстракорпорального запліднення (EKЗ/ICSI).

Результати. Після включення в програму допоміжних репродуктивних технологій усіх жінок було обстежено та поділено на 2 групи залежно від лікувальної схеми: I група (контрольна) включала 51 пацієнтку 3 ендометріозасоційованим безпліддям, яким проводили контрольовану оваріальну стимуляцію (КОС) за допомогою стандартного довгого протоколу; II група (дослідна) - 53 жінки з ендометріозасоційованим безпліддям, яким проводили модиоріковану схему КОС. Для оцінки есрективності лікування із застосуванням прегравідарної терапії використовували такі показники: сумарна доза рекомбінантного фолікулостимулювального гормону (р-ФСГ), тривалість стимуляції, кількість фролікулів діаметром більше 17 мм на момент введення тригера фрінального дозрівання фолікулів, сумарний коефріцієнт ефективності отриманих ооциткумулюсних комплексів при трансвагінальній пункції, ступінь зрілості ооцитів, частота дегенеративних змін в яйцеклітинах, відсоток запліднення, дроблення ембріонів, вихід бластоцист.

Висновки. Прегравідарна терапія комбінацією препаратів інозитолу та вітаміну D підвищує чутливість яєчників до стимуляції та покращує результати допоміжних репродуктивних технологій. Проведення оперативних втручань у пацієнток із генітальним ендометріозом I та II ступенів тяжкості рекомендовано після стимуляції суперовуляції у програмах допоміжних репродуктивних технологій.
\end{abstract}

КЛЮЧОВІ СЛОВА: ендометріоз; безпліддя; антиоксидантна терапія; допоміжні репродуктивні технології.

Ендометріоз - це одне із найпоширеніших гінекологічних захворювань в Україні та світі. Згідно 3 дослідженнями науковців, кожна десята жінка репродуктивного віку страждає від ендометріозу, що становить 176 млн жінок (World Population Projection Tables by Country and Group, 2010). Ендометріоз діагностують переважно у молодих працездатних жінок 30-35 років (87,7 \%), що визначає високу соціальну значущість проблеми. Визначають чітку тенденцію до подальшого зростання цього захворювання у світі (від 0,05 до $0,2 \%$ ). Це пов'язано $з$ раннім початком статевого життя, перериванням вагітності, пізньою реалізацією репродуктивної срункції. За даними різних авторів, частота захворювання варіює від 8 до 52 \% та може спостерігатися в будь-якій віковій групі, не залежить від соціально-економічних умов життя та етнічної приналежності [1-3].

Основними симптомами ендометріозу $€$ безпліддя, менорагія, дисменорея, диспареунія, хронічний тазовий біль. У $20-25 \%$ жінок це захворювання перебігає безсимптомно. Частота ви-

(c) С. В. Хміль, І. І. Кулик, Р. П. Микула, 2018 явлення пацієнток із безпліддям становить у середньому 35-44 \%, а іноді сягає $48 \%$. У більшості випадків виявляють генітальний ендометріоз (92$94 \%$ ), значно рідше - екстрагенітальний ендометріоз (6-8 \%) [4]. Кожна десята жінка репродуктивного віку хвора на ендометріоз, 2/3 з них - віком до 30 років, $1 / 5$ - до 19 років [5].

Ендометріоз належить до мультифракторних захворювань, що характеризується системною запальною реакцією. Провідною ланкою патогенезу генітального ендометріозу та безпліддя вважають хронічний запальний процес та порушення механізмів оксидантного захисту, внаслідок яких порушується фрункція яєчників, імплантація ембріонів та знижується фрертильність [6].

Диссрункція гіпоталамо-гіпофізарно-яєчникової системи зумовлює порушення фолікулогенезу внаслідок пролонгованої фролікулярної фрази, низького рівня сироваткового естрадіолу, зниження пікової концентрації лютеїнізуючого гормону, порушення резистентності до прогестерону. У жінок із ендометріозасоційованим безпліддям порушується виділення лютеїнізуючого гормону, 
тому настання синдрому передчасної лютеїнізації фролікула спостерігають в них частіше, ніж у жінок з іншими формами безпліддя $[7,8]$.

Окрім порушень фролікулогенезу, в даної групи жінок варто відзначити порушення скоротливої діяльності матки. За рахунок хронічного запального процесу та каскаду біохімічних реакцій в малому тазі вивільняється надмірна кількість простагландинів, що провокують утеротубальну дисперистальтику, наслідком якої $€$ порушення транспорту гамет та ембріона $[9,10]$.

Підвищений рівень IL-6 в перитонеальній рідині у жінок із генітальним ендометріозом частково пригнічує рухомість сперматозоїдів, запальні медіатори можуть спричинити ушкодження ДНК сперматозоїдів [11]. Оскільки ендометріоз вважають хронічним запальним захворюванням, багато досліджень спрямовані на пошук нових методів лікування, що змогли б моделювати реакцію медіаторів запалення, покращувати фолікулогенез та відповідь яєчників на стимуляцію овуляції. Удосконалення вже існуючих та пошук нових методів лікування дають змогу не лише покращити результати лікування безпліддя, але й якість життя жінок. Таким чином, розроблено нові тактики лікування, які спрямовані на боротьбу з порушенням регуляції системи імунітету та оксидантного захисту, що характерні для ендометріозу [12].

Основним методом лікування ендометріозасоційованого безпліддя вважають використання допоміжних репродуктивних технологій (ДРТ). Доцільність застосування медикаментозної терапії та хірургічного лікування визначають для кожної пацієнтки індивідуально. Використання екстракорпорального запліднення (ЕКЗ) як терапії першої лінії збільшує коефріцієнт вагітностей до 56,1% порівняно зі значно зниженою частотою вагітностей 37,4 \% після оперативного лікування [13].

Aboulghar et al. та інші науковці вважають недоцільним проведення оперативного лікування та затяжної супресивної медикаментозної терапії перед протоколом КОС, оскільки ця терапія погіршує відповідь яєчників на стимуляцію, зменшує кількість зрілих ооцитів та якісних ембріонів [14]. Протокол стимуляції (довгий протокол 3 агоністами гонадотропних рилізинг-гормонів чи короткий протокол з антагоністами гонадотропних рилізинг-гормонів) немає принципового значення, оскільки якість та кількість яйцеклітин та ембріонів, отриманих у результаті стимуляції, не мають суттєвих відмінностей [15].

За результатами Кокранівського огляду, 50 рандомізованих контрольованих досліджень - комбіновані пероральні антиоксиданти (вітаміни, мінерали та мікроелементи), покращують результати лікування безпліддя, показники живонародження і клінічні показники вагітності у жінок із безпліддям на фроні ендометріозу. Щоденне приймання антиоксидантів в якості прегравідарної терапії моделюють імунну систему та запальні процеси, які змінюються на фроні ендометріозу в жінок із безпліддям [16].

1,25-дигідроксивітамін-D (вітамін D), крім кальцій-фросфратного гомеостазу, має виражений імуномодулюючий ефект (впливає аутокринним/ паракринним способом на місцеве імунне середовище), впливає на процеси проліферації та диференціації клітин. Дослідження показали, що приймання вітаміну D зменшує концентрацію протизапальних цитокінів: IL-6, інтерферон-g, IL-2, і TNF- $\alpha$. Під час імплантації 1,25 (OH) $2 \mathrm{D}_{3}$ активує каскад генів, білкові продукти яких беруть участь в процесі імплантації: трофобластноендометріальні взаємодії [17].

Виявлено позитивний кореляційний зв'язок між рівнем вітаміну D у сироватці крові та фролікулярній рідині та клінічними вагітностями після ЕКЗ (підвищена ймовірність досягнення на $6 \%$, $\mathrm{p}=0,030)$ [18].

Якість яйцеклітин залежить від балансу оксидантів та антиоксидантів в організмі людини. У жінок із ендометріозасоційованим безпліддям часто спостерігають порушення антиоксидантного статусу, та, як наслідок, погану якість ооцитів, погану відповідь на стимуляцію в протоколах контрольованої оваріальної стимуляції, порушення імплантації [19]. Науковці відзначають, що жінки, які хворіють на ендометріоз, мають порушення вуглеводного та ліпідного обмінів, зокрема порушується експресія білка GLUT4 (глюкозо-4транспортази), що сприяє накопиченню глюкози в гетеротопіях [20]; та спостерігають «несприятливий» ліпідний профріль (збільшення ліпідів низької щільності та зниження ліпопротеїдів високої щільності), внаслідок чого через систему пероксидного окиснення ліпідів потенціюється окиснювальний стрес [21, 22].

Інозитол $€$ компонентом фосфроліпідів та входить до складу цитоплазматичних мембран як фоссроінозитид. Інозитол зв'язує $\mathrm{Ca}_{2+}$ канали та стимулює внутрішньоклітинне вивільнення $\mathrm{Ca}_{2+}$. Збільшення внутрішньоклітинного рівня $\mathrm{Ca}_{2+}$ відіграє важливу роль в дозріванні, заплідненні ооцитів та розвитку ембріона. Достатня концентрація інозитолу в фролікулярній рідині знижує рівень вільних радикалів та ушкодження мембранних білків та збільшує кількість ооцитів доброї якості. Його дефіцит призводить до атрезії фолікула [23].

Вітамін C $є$ потужним природним антиоксидантом. Знижений рівень вітаміну С або його відсутність призводить до атрезії фолікулів. У жінок 3 ендометріозом спостерігають зниження рівня вітаміну С у фолікулярній рідині у зв'язку з його надмірним споживанням як антиоксиданту для нейтралізації активних фрорм кисню (АФК) у клітині. Щоденне приймання вітамінів та мінералів 
забезпечує оптимальну ферментативну активність антиоксидантів, зменшує вироблення вільних радикалів та прояви оксидативного стресу, а отже, покращує загальне самопочуття жінки та якість яйцеклітин і ембріонів [24].

Мета дослідження: підвищити результативність протоколів допоміжних репродуктивних технологій з використанням комплексної прегравідарної терапії у жінок із безпліддям на фроні генітального ендометріозу.

Матеріали і методи. Рандомізоване клініколабораторне дослідження було проведено серед 104 пацієнток репродуктивного віку з безпліддям та гістологічно підтвердженим діагнозом генітального ендометріозу. Лікування безпліддя всім пацієнткам було проведено із застосуванням допоміжних репродуктивних технологій - екстракорпорального запліднення.

Обстеження та лікування пацієнтів проводили відповідно до наказу Міністерства охорони здоров'я України від 09.09.2013 р. № 787 «Про затвердження Порядку застосування допоміжних репродуктивних технологій в Україні» та наказу Міністерства охорони здоров'я України від 29.11.2013 р. № 1030/102 «Про удосконалення системи планування сім'ї та охорони репродуктивного здоров'я в Україні» $[25,26]$.

Критерії включення пацієнток у дослідну групу:

- репродуктивний вік;

- рівень фролікулостимулювального гормону (ФСГ) $\leq 12 \mathrm{MO} / л$;

- рівень антимюлерового гормону (АМГ) 21,0 нг/мл;

- гістологічно підтверджений діагноз генітального ендометріозу;

- здоровий соматичний та психічний стан, відсутність інфекційних захворювань і тяжких супутніх захворювань, що є протипоказаннями до застосування методик ДРТ, та хронічних захворювань у стадії загострення;

- добровільна згода пацієнтки на участь у дослідженні.

Критеріями виключення були:

- вік пацієнток $\geq 40$ років;

- ендометріоз III-IV ступенів;

- загальні протипоказання для протоколу ЕКЗ і настання вагітності.

Середній вік обстежених нами жінок 3 ендометріозасоційованим безпліддям в основній групі становив $(31,9 \pm 4,0)$ року, що було приблизно однаково з віком жінок із контрольної групи. Середня маса тіла жінок основної групи склала $(71,8 \pm 8,4)$ кг, а у контрольній групі - $(72,6 \pm 9,2)$ кг.

Тривалість безпліддя серед обстежених пацієнток склала від 3 до 10 років при середньому значенні $(6,2 \pm 1,4)$ року. Первинне безпліддя виявлено у 63 пацієнток із 94 (67\%), вторинне у 31 пацієнтки (33 \%). Отримані результати опрацьовано за допомогою методу варіаційної статистики шляхом обчислення середнього арифметичного значення та його похибки, критерія Стьюдента та рівня значущості (p).

Результати дослідження та їх обговорення. Після включення в програму ДРТ і проведення стандартного обстеження пацієнток, які дали згоду на участь у дослідженні, їх поділили на 2 групи залежно від лікувальної схеми:

- І група (контрольна) - 51 жінка з ендометріозасоційованим безпліддям, яким проводили КОС за допомогою стандартного довгого протоколу (протокол з а-ГнРГ). Дану групу поділили на 2 підгрупи: 26 жінок в анамнезі мали хірургічну кістектомію та 25 пацієнток без хірургічного втручання;

- II група (дослідна) - 53 жінки 3 ендометріозасоційованим безпліддям, яким проводили модифріковану схему КОС: протокол 3 а-ГнРГ та ад'ювантну терапію вітамінного комплексу «FT-500 Plus», який містить інозитол 2000 мг (вітамін $\mathrm{B}_{8}$ ), вітамін C - 160 мг, вітамін E - 12 мг, фолієву кислоту - 400 мкг, селен - 55 мкг, глютатіон - 50 мг, цинк - 10 мг, лютеїн - 3 мг, один пакетик 1 раз на добу та вітаміном $D$ «Олігодетрим» у середньотерапевтичних дозах за 2-3 місяці до початку стимуляції овуляції. Дану групу поділили на 2 підгрупи: 27 пацієнток в анамнезі мали хірургічну кістектомію та 26 жінок без хірургічного втручання.

Вивчали стан гіпоталамо-гіпофрізарно-яєчникової системи у ранній фолікулярній фазі менструального циклу. Динаміку рівнів концентрації гормонів у плазмі крові визначали на 2-3 доби: фолікулостимулювального та лютеїнізуючого (ЛГ) гормонів, пролактину (ПРЛ), естрадіолу (Е2) та антимюлерового гормону, а на 19-21 доби оваріо-менструального циклу - прогестерону (ПГ). Показники у сироватці крові лютеїнізуючого гормону, пролактину, естрадіолу та прогестерону в порівнюваних групах клінічного дослідження перебували у межах рефрерентних значень та статистично значущих відмінностей за їх змістом між групами ми не виявили $(p>0,05)$. Визначення основних маркерів стану фролікулярного апарату показало, що середній рівень ФСГ склав у середньому $(6,6 \pm 1,73)$ МО/мл. Маркер фолікулярного резерву - АМГ склав у середньому $(1,06 \pm 0,33)$ нг/мл. Отримані показники сироваткових концентрацій АМГ та ФСГ могли свідчити про нормальний фролікулярний резерв у двох досліджуваних клінічних групах та передбачуваній адекватній відповіді на стимуляцію суперовуляції.

Після аналізу гінекологічного анамнезу в пацієнток $з$ ендометріозасоційованим безпліддям статистично значущих відмінностей не виявлено. У всіх пацієнток використовували довгий протокол стимуляції 3 а-ГнРГ «Диферелін» 3,75 (препарат вводили внутрішньом'язово на 19-22 дні циклу), в якості індуктора стимуляції росту фолікулів застосовували рекомбінантний гонадотропін 
корифролітропін-альфра «ЕЛОНВА» та додатково р-ФСГ «Пурегон». Дозу р-ФСГ підбирали індивідуально з урахуванням гормональних показників та віку пацієнток. В якості тригера овуляції використовували рекомбінантний ХГЛ, цей препарат призначали пацієнтам у випадку трьох і більше фолікулів діаметром 18 мм.

Аспірацію ооцитів проводили через 36 год після введення тригера овуляції, запліднення яйцеклітин та культивування ембріонів із подальшою ймовірною вітрифрікацією або транссрером у порожнину матки на 5-6 доби (стадія бластоцисти) здійснювали в умовах ембріологічної лабораторії.

Оцінку яйцеклітин проводили після денудації, перед процедурою ICSI. Описували генетичну зрілість яйцеклітин (GV, MI, MII). Морфометричні параметри ооцитів визначали за допомогою наступних параметрів: оцінки прозорої оболонки (zona pellucida) та її зовнішнього вигляду, структури та товщини, зміни у величині та фрормі самого ооцита, якості цитоплазми (наявність цитоплазматичних включень, вакуолізація, цитоплазматична зернистість), характеристики перивітелінового простору, стану полярного тіла [27].
Оцінку отриманих зигот проводили через 1619 год після процедури ICSI - співвідношенням зигот із двома пронуклеусами до загальної кількості клітин, що запліднювали. Якість дроблення ембріонів описували наявністю фрагментації цитоплазми та кількості й симетрією бластомерів. Вихід бластоцист оцінювали на 5-6 доби. Якісну характеристику ембріонів на стадії бластоцисти проводили за системою Gardner [28]. Після перенесення ембріонів у порожнину матки, пацієнтки отримували підтримувальну терапію до отримання результату на

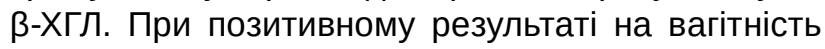
підтримку продовжували до 10-12 тижнів.

Для визначення ефективності лікування із застосуванням прегравідарної терапії використовували такі показники: сумарна доза р-ФСГ, тривалість стимуляції, кількість фролікулів діаметром більше 17 мм на момент введення тригера фрінального дозрівання фролікулів, сумарний коефіцієнт ефективності отриманих ооциткумулюсних комплексів при ТВП (з промиванням фолікулів та без), ступінь зрілості ооцитів, частота дегенеративних змін в яйцеклітинах (морфометричні параметри), відсоток запліднення, дроблення ембріонів, вихід бластоцист (табл. 1, 2).

Таблиця 1. Показники ефективності використання прегравідарної терапії у пацієнток із ендометріозасоційованим безпліддям, яким проводили хірургічне втручання

\begin{tabular}{|l|c|c|c|}
\hline \multirow{2}{*}{ Критерії оцінки } & I група (контрольна) $\mathrm{n=25}$ & $\begin{array}{c}\text { II група } \\
\text { (дослідна) } \mathrm{n}=27\end{array}$ & $\mathrm{p}$ \\
\cline { 2 - 3 } & кістектомія & $226,5 \pm 1,7$ & $>0,05$ \\
\hline Сумарна доза р-ФСГ (МО) & $249,3 \pm 2,1$ & $11,3 \pm 1,5$ & $>0,05$ \\
\hline Тривалість стимуляції (дні) & $11,8 \pm 1,3$ & $11,4 \pm 1,6$ & $<0,05$ \\
\hline Кількість фолікулів & $10,1 \pm 1,1$ & $82,1 \pm 1,8$ & $>0,05$ \\
\hline $\begin{array}{l}\text { Сумарний коефіцієнт есрективності } \\
\text { отриманих ооцитів (\%) }\end{array}$ & $79,4 \pm 2,1$ & & $<0,05$ \\
\hline Ступінь зрілості ооцитів (\%) & $73,5 \pm 3,1$ & $79,3 \pm 2,7$ & $>0,05$ \\
\hline Частота дегенеративних ооцитів (\%) & $17,2 \pm 1,9$ & $13,3 \pm 2,2$ & $<0,05$ \\
\hline Запліднення (\%) & $72,7 \pm 3,4$ & $76,1 \pm 2,8$ & $>0,05$ \\
\hline Дроблення (\%) & $59,7 \pm 1,7$ & $63,4 \pm 2,3$ & $<0,05$ \\
\hline Вихід бластоцист (\%) & $38,9 \pm 2,4$ & $43,0 \pm 2,2$ & \\
\hline
\end{tabular}

Таблиця 2. Показники ефективності використання прегравідарної терапії у пацієнток із ендометріозасоційованим безпліддям без хірургічного втручання

\begin{tabular}{|l|c|c|c|}
\hline \multirow{2}{*}{ Критерії оцінки } & I група (контрольна) $\mathrm{n}=25$ & II група (дослідна) $\mathrm{n}=27$ & \multirow{2}{*}{$\mathrm{p}$} \\
\cline { 2 - 3 } & без хірургічного втручання & без хірургічного втручання & $>0,05$ \\
\hline Сумарна доза р-ФСГ (МО) & $237,4 \pm 2,1$ & $217,6 \pm 1,7$ & $>0,05$ \\
\hline Тривалість стимуляції (дні) & $11,3 \pm 1,1$ & $11,1 \pm 1,3$ & $>0,05$ \\
\hline Кількість фролікулів & $15,3 \pm 1,4$ & $15,8 \pm 1,1$ & $<0,05$ \\
\hline $\begin{array}{l}\text { Сумарний коефіцієнт есрективності } \\
\text { отриманих ооцитів (\%) }\end{array}$ & $86,1 \pm 2,3$ & $89,5 \pm 1,7$ & $<0,05$ \\
\hline Ступінь зрілості ооцитів (\%) & & & $>0,05$ \\
\hline Частота дегенеративних ооцитів (\%) & $81,3 \pm 2,1$ & $83,3 \pm 2,3$ & $>0,05$ \\
\hline Запліднення (\%) & $14,1 \pm 1,5$ & $10,4 \pm 1,1$ & $>0,05$ \\
\hline Дроблення (\%) & $75,8 \pm 1,6$ & $79,6 \pm 1,4$ & $<0,05$ \\
\hline Вихід бластоцист (\%) & $62,3 \pm 2,2$ & $64,8 \pm 2,4$ & \\
\hline
\end{tabular}


Пацієнтки II групи, яким не проводили кістектомію перед процедурою ЕКЗ, мали достовірно вищі показники оцінки ефективності лікування.

\section{Висновки}

1. Використання комбінації препаратів інозитолу та вітаміну D як прегравідарна терапія підвищує чутливість яєчників до стимуляції, що проявляється у зменшенні сумарної дози препаратів, які використовують в протоколах КОС.

2. Застосування модифрікованих схем коС 3 ад'ювантною терапією із метою корекції оксидативних порушень під час КОС дозволяє збільшити кількість ооцитів, покращити ступінь їх зрілості та якості, коефіцієнт запліднення та вихід бластоцист у хворих із безпліддям на фроні генітального ендометріозу.

3. У пацієнток із генітальним ендометріозом I та II ступенів тяжкості рекомендовано проведення хірургічних втручань після стимуляції суперовуляції у програмах ДРТ.

Перспективи подальших досліджень. Етіологія генітального ендометріозу складна та багатофакторна, враховуючи це, необхідно розробити комплексний підхід до діагностики та лікування з урахуванням усіх ланок патогенезу цього захворювання.

\section{Список літератури}

1. Prevalence and incidence of diagnosed endometriosis and risk of endometriosis in patients with endometriosis-related symptoms: findings from a statutory health insurancebased cohort in Germany / S. Abbas, P. Ihle, I. Koster, I. Schubert // Eur. J. Obstet. Gynecol. Reprod. Biol. - 2012. - Vol. 160. - P. 79-83.

2. Fuldeore M. J. Prevalence and symptomatic burden of diagnosed endometriosis in the United States: national estimates from a cross-sectional survey of 59,411 women / M. J. Fuldeore, A. M. Soliman // Gynecol. Obstet. Invest. - 2016. DOI:10.1159/ 000452660.

3. High prevalence of endometriosis in infertile women with normal ovulation and normospermic partners / C. Meuleman, B. Vandenabeele, S. Fieuws [et al.] // Fertil. Steril. - 2009. - Vol. 92. - P. 68-74.

4. Кира Е. Ф. Эндометриоидная болезнь / Е. Ф. Кира, Ю. В. Цвелев, В. Н. Серова. - М. : Литера, $2008 .-840$ с.

5. Юренева С. В. Эндометриоз - заболевание «вне возраста» (от пубертатного периода до постменопаузы) / С. В. Юренева // Проблемы репродукции. - 2011. - № 4. - С. 67-74.

6. Do endometriomas induce an inflammatory reaction in nearby follicles? / H. K. Opoien, P. Fedorcsak, A. Polec [et al.] // Hum. Reprod. - 2013. - Vol. 28. - P. 1837-1845.

7. Cahill D. J. Pituitary-ovarian dysfunction and endometriosis / D. J. Cahill, M. G. Hull // Hum. Reprod. Update. - 2000. Vol. 6. - P. 56-66.

8. Progesterone resistance in endometriosis: origins, consequences and intervention / B. G. Patel, M. Rudnicki, J. Yu [et al.] // Acta Obstet. Gynecol. Scand. - 2017. - Vol. 96 (6). - P. 623-632. doi: 10.1111/aogs.13156.s.

9. Yoshida S. A combination of interleukin- 6 and its soluble receptor impairs sperm motility: implications in infertility associated with endometriosis / S. Yoshida, T. Harada, T. Iwabe // Hum. Reprod. - 2004. - Vol. 19. - P. 1821-1825.

10. The impact of peritoneal fluid from healthy women and from women with endometriosis on sperm DNA and its relationship to the sperm deformity index / G. Mansour, N. Aziz, R. Sharma [et al.] // Fertil. Steril. - 2009. - Vol. 92. - P. 61-67.

11. Gupta S. Potential markers of endometriosis: Latest update / S. Gupta, A. Sinha // J. Genit. Syst. Disord. - 2016. Vol. 5. - P. 3.

12. Practice Committee of the American Society for Reproductive Medicine (ASRM). Endometriosis and Infertility // Fertil. Steril. - 2006. - Vol. 14. - P. S156-60.

13. Endometriosis and infertility surgery and ART: an integrated approach for successful management / M. E. Coccia, F. Rizzello, F. Cammilli // Eur. J. Obstet. Gynecol. Reprod. Biol. - 2008. - Vol. 138 (1). - P. 54-59.

14. The outcome of in vitro fertilization in advanced endometriosis with previous surgery: a case-controlled study 1 M. A. Aboulghar, R. T. Mansour, G. I. Serour [et al.] // Am. J. Obstet. Gynecol. - 2003. - Vol. 188 (2). - P. 371-375.

15. Pabuccu R. GnRH agonist and antagonist protocols for stage I-II endometriosis and endometrioma in vitro fertilization/ intracytoplasmic sperm injection cycles / R. Pabuccu, G. Onalan, C. Kaya // Fertil. Steril. - 2007. - Vol. 88. - P. 832-839. 16. Cochrane Central Register of Controlled Trials. Use of Antioxidant in Endometriotic Women to Improve Intracytoplasmic Sperm Injection (ICSI) / 2014. added to CENTRAL: 31 May 2018. - 2018. - Issue 5. ClinicalTrials.gov Identifier: NCT02058212

17. Vitamin $D$ in endometriosis: a causative or confounding factor? / L. Sayegh, Gel-H. Fuleihan, A. H. Nassar // Metabolism. - 2014. - Vol. 63 (1). - P. 32-41.

18. Vitamin $D$ deficiency and pregnancy rates in women undergoing single embryo, blastocyst stage, transfer (SET) for IVF/ICSI / N. P. Polyzos, E. Anckaert, L. Guzman [et al.] // Human Reproduction. - 2014. - Vol. 29 (9). - P. 2032-2040.

19. Effect of apoptosis and reactive oxygen species production in human granulosa cells on oocyte fertilization and blastocyst development / N. Jancar, A. N. Kopitar, A. Ihan [et al.] // J. Assist. Reprod. Genet. - 2007. - Vol. 24 (2-3). P. 91-97.

20. Glucose transporter expression in eutopic endometrial tissue and ectopic endometriotic lesions / B. McKinnon, D. Bertschi, C. Wotzkow [et al.] // J. Mol. Endocrinol. - 2014. - Vol. 52 (2). - P. 169-179.

21. Unfavorable lipid profile in women with endometriosis / A. S. Melo, J. C. Rosa-e-Silva, A. C. Rosa-e-Silva [et al.] // Fertil. Steril. - 2010. - Vol. 93 (7). - P. 2433-2436.

22. Low-density lipoproteins oxidation and endometriosis / G. Polak, B. Barczyński, W. Kwaśniewski [et al.] // Mediators Inflamm. - 2013. - Vol. 2013. - P. 624540. 
23. Inositol and in vitro fertilization with embryo transfer / G. Simi, A. R. Genazzani, M. E. R. Obino [et al.] // International Journal of Endocrinology. - Vol. 2017. - 5 p. Article ID 5469409.

24. Thomas D. R. Vitamins in aging, health, and longevity / D. R. Thomas // Clinical Interventions in Aging. - 2006. Vol. 1 (1). - P. 81-91.

25. Про затвердження Порядку застосування допоміжних репродуктивних технологій в Україні : наказ Міністерства охорони здоров'я України від 09.09.2013 р. № 787.

26. Про удосконалення системи планування сім'ї та охорони репродуктивного здоров'я в Україні : наказ Міністерства охорони здоров'я України від 29.11.2013 р. № 1030/102.

27. Lazzaroni-Tealdi E. Oocyte scoring enhances embryo-scoringin predicting pregnancy chances with IVF where it counts most / E. Lazzaroni-Tealdi, D. H. Barad // Plos One. - 2015. - Vol. 2. - P. 1-13. DOI:10.1371/journal.

28. Blastocysts coreaffects implantation and pregnancy outcome: towards a single blastocyst transfer / D. K. Gardner, M. Lane, J. Stevens [et al.] // Fertility and Sterility. - 2000. - Vol. 6. - P. 1155-1158.

\section{References}

1. Abbas, S., Ihle, P., Koster, I., \& Schubert, I. (2012). Prevalence and incidence of diagnosed endometriosis and risk of endometriosis in patients with endometriosis-related symptoms: findings from a statutory health insurancebased cohort in Germany. Eur. J. Obstet. Gynecol. Reprod. Biol., 160, 79-83.

2. Fuldeore, M.J., \& Soliman, A.M. (2016). Prevalence and symptomatic burden of diagnosed endometriosis in the United States: national estimates from a cross-sectional survey of 59,411 women. Gynecol. Obstet. Invest. DOI:10.1159/ 000452660.

3. Meuleman, C., Vandenabeele, B., Fieuws, S., Spiessens, C., Timmerman, D., \& Hooghe, T. (2009). High prevalence of endometriosis in infertile women with normal ovulation and normospermic partners. Fertil. Steril., 92, 68-74.

4. Kira, Ye.F., Tsvelev, Yu.V., \& Serova, V.N. (2008). Endometrioidnaya bolezn [Endometrial disease]. Moscow: Litera [in Russian].

5. Yureneva, S.V. (2011). Endometrioz - zabolevaniye "vne vozrasta" (ot pubertatnogo perioda do postmenopauzy) [Endometriosis - a disease "out of age" (from puberty to post-menopause)]. Problemy reproduktsii - Reproduction Problems, 4, 67-74 [in Russian].

6. Opoien, H.K., Fedorcsak, P., Polec, A., Stensen, M.H., Abyholm, T., \& Tanbo, T. (2013). Do endometriomas induce an inflammatory reaction in nearby follicles? Hum. Reprod., 28, 1837-1845.

7. Cahill, D.J., \& Hull, M.G. (2000). Pituitary-ovarian dysfunction and endometriosis. Hum. Reprod. Update, 6, 56-66.

8. Patel, B.G., Rudnicki, M., Yu, J., Shu, Y., \& Taylor, R.N. (2017). Progesterone resistance in endometriosis: origins, consequences and intervention. Acta Obstet. Gynecol. Scand., 96 (6), 623-632. doi: 10.1111/aogs.13156.s.

9. Mansour, G., Aziz, N., Sharma, R., Falcone, T., Goldberg, J., \& Agarwal, A. (2009). The impact of peritoneal fluid from healthy women and from women with endometriosis on sperm DNA and its relationship to the sperm deformity index. Fertil. Steril., 92, 61-67.

10. Gupta, S., \& Sinha, A. (2016). Potential markers of endometriosis: Latest update. J. Genit. Syst. Disord., 5, 3.

11. Practice Committee of the American Society for Reproductive Medicine (ASRM). (2006). Endometriosis and Infertility. Fertil. Steril., 14, S156-160.

12. Coccia, M.E., Rizzello, F., Cammilli, F., Bracco, G.L., \& Scarselli, G. (2008). Endometriosis and infertility surgery and ART: an integrated approach for successful management. Eur. J. Obstet. Gynecol. Reprod. Biol., 138 (1), 54-59.

13. Aboulghar, M.A., Mansour, R.T., Serour, G.I., Al-Inany, H.G., \& Aboulghar, M.M. (2003). The outcome of in vitro fertilization in advanced endometriosis with previous surgery: a case-controlled study. Am. J. Obstet. Gynecol., 188 (2), 371-375.

14. Pabuccu, R., Onalan, G., \& Kaya, C. (2007). GnRH agonist and antagonist protocols for stage I-II endometriosis and endometrioma in vitro fertilization/intracytoplasmic sperm injection cycles. Fertil. Steril., 88, 832-839.

15. Cochrane Central Register of Controlled Trials. (2018). Use of Antioxidant in Endometriotic Women to Improve Intracytoplasmic Sperm Injection (ICSI). Issue 5. Added to CENTRAL: 31 May 2018.

16. Sayegh, L., Fuleihan, Gel-H., \& Nassar, A.H. (2014). Vitamin D in endometriosis: a causative or confounding factor? Metabolism, 63, 32e41.

17. Polyzos, N.P., Anckaert, E., Guzman, L., Schiettecatte, J., Van Landuyt, L., Camus, M., ... Tournaye, H. (2014). Vitamin D deficiency and pregnancy rates in women undergoing single embryo, blastocyst stage, transfer (SET) for IVF/ICSI. Human Reproduction, 29 (9), 2032-2040.

18. Jancar, N., Kopitar, A.N., Ihan, A., Virant Klun, I., \& Bokal, E.V. (2007). Effect of apoptosis and reactive oxygen species production in human granulosa cells on oocyte fertilization and blastocyst development. J. Assist. Reprod. Genet., 24 (2-3), 91-97.

19. McKinnon, B., Bertschi, D., Wotzkow, C., Bersinger, N.A., Evers, J., \& Mueller, M.D. (2014). Glucose transporter expression in eutopic endometrial tissue and ectopic endometriotic lesions. J. Mol. Endocrinol., 52 (2), 169-179.

20. Melo, A.S., Rosa-e-Silva, J.C., Rosa-e-Silva, A.C., Poli-Neto, O.B., Ferriani, R.A., \& Vieira C.S. (2010). Unfavorable lipid profile in women with endometriosis. Fertil. Steril., 93 (7), 2433-2436.

21. Polak, G., Barczynski, B., Kwasniewski, W., Bednarek, W., Wertel, I., Derewianka-Polak, M, ... \& Kotarski, J. (2013). Low-density lipoproteins oxidation and endometriosis. Mediators Inflamm., 2013, 624540.

22. Simi, G., Genazzani, A.R., Obino, M.E.R., Papini, F., Pinelli, S., Cela, V., \& Artini, P.G. (2017). Inositol and in vitro fertilization with embryo transfer. International Journal of Endocrinology, 5469409, 5.

23. David, R. (2006). Thomas. Vitamins in aging, health, and longevity. Clinical Interventions in Aging, 1 (1), $81-91$. 
24. David, R. (2006). Thomas. Vitamins in aging, health, and longevity. Clinical Interventions in Aging, 1 (1), 81-91.

25. On Approval of the Procedure for the Use of Assisted Reproductive Technologies in Ukraine. Order of the Ministry of Health of Ukraine dated 09.09.2013.

26. On Improvement of Family Planning and Reproductive Health System in Ukraine. Order of the Ministry of Health of Ukraine dated 11/29/2013. No.1030/102.

27. Lazzaroni-Tealdi, E., \& Barad, D.H. (2015). Oocyte scoring enhances embryo-scoring in predicting pregnancy chances with IVF where it counts most. PLOS ONE, 2, 1-13. DOI:10.1371/journal.

28. Gardner, D.K., Lane, M., Stevens, J., Schlenker, T., \& Schoolcraft, W.B. (2000). Blastocyst score affects implantation and pregnancy outcome: towards a single blastocyst transfer. Fertil. Steril., 73 (6), 1155-1158.

\section{АНТИОКСИДАНТНАЯ ТЕРАПИЯ У ЖЕНЩИН С БЕСПЛОДИЕМ НА ФОНЕ ЭНДОМЕТРИОЗА}

С. В. Хмиль ${ }^{1,2}$, И. И. Кулик ${ }^{2}$ Р. П. Микула ${ }^{2}$

${ }^{1}$ ГВУЗ «Тернопольский государственный медицинский университет имени И. Я. Горбачевского МЗ Украины»,

г. Тернополь, Украина

${ }^{2}$ Медицинский центр «Клиника профрессора С. Хмиля», г. Тернополь, Украина

Цель: повысить результативность протоколов вспомогательных репродуктивных технологий с использованием комплексной прегравидарной терапии у женщин с бесплодием на фоне генитального эндометриоза.

Материалы и методы. Рандомизированное клинико-лабораторное исследование было проведено среди 104 пациенток репродуктивного возраста с бесплодием и гистологически подтвержденным диагнозом генитального эндометриоза. Лечение бесплодия всем пациенткам было проведено с применением вспомогательных репродуктивных технологий - экстракорпорального оплодотворения (ЭКО/ICSI).

Результаты. После включения в программу вспомогательных репродуктивных технологий (BPT) всех женщин обследовали и разделили на 2 группы в зависимости от лечебной схемы: I группа (контрольная) - включала 51 пациентку с эндометриозассоциированным бесплодием, которым проводили КОС с помощью стандартного длинного протокола; II группа (исследовательская) - 53 женщины с эндометриозассоциированным бесплодием, которым проводили модифицированную схему КОС. Для оценки эффективности лечения с применением прегравидарной терапии использовали следующие показатели: суммарная доза р-ФСГ, продолжительность стимуляции, количество фоолликулов диаметром более 17 мм на момент введения триггера фринального созревания фролликулов, суммарный коэффрициент эфрфективности полученных ооциткумулюсных комплексов при трансвагинальной пункции, степень зрелости ооцитов, частота дегенеративных изменений в яйцеклетках, процент оплодотворения, дробление эмбрионов, выход бластоцист.

Выводы. Прегравидарная терапия комбинацией препаратов инозитола и витамина D повышает чувствительность яичников к стимуляции и улучшает результаты вспомогательных репродуктивных технологий. Проведение оперативных вмешательств у пациенток с генитальным эндометриозом I и II степеней тяжести рекомендуется после стимуляции суперовуляции в программах ВРT.

КЛЮЧЕВЫЕ СЛОВА: эндометриоз; бесплодие; антиоксидантная терапия; вспомогательные репродуктивные технологии.

\section{ANTIOXIDANT THERAPY IN WOMEN WITH ENDOMETRIOSIS DEPENDENT INFERTILITY}

S. V. Khmil,2, I. I. Kulyk ${ }^{2}$, R. P. Mykula ${ }^{2}$

1. Horbachevsky Ternopil State Medical University

${ }^{2}$ Medical Center "Clinic of Professor S. Khmil", Ternopil, Ukraine

Purpose: to increase the effectiveness of auxiliary reproductive technologies protocols using integrated pregravid therapy, in women with genital endometriosis infertility.

Materials and Methods. A randomized, clinical trial was conducted on 104 pregnant women with infertility and histologically confirmed diagnosis of genital endometriosis. Infertility treatment for all patients was performed using auxiliary reproductive technologies - extracorporeal fertilization of IVF / ICSI.

Results. After inclusion in the assisted reproductive technology program, all women were examined and divided into 2 groups depending on the treatment protocol: group I (control) included 51 patients with endometriosis-associated infertility, which was performed by the COS using a standard "long" protocol. This group was divided into 2 subgroups; group II - (experimental) 53 women with endometriosis-associated infertility, who were undergoing a modified COS scheme. The evaluation of the effectiveness of treatment with the use of pregravid therapy was based on the following parameters: total dose of $\mathrm{p}-\mathrm{FSH}$, duration of stimulation, the number of follicles in diameter greater than $17 \mathrm{~mm}$ at the time of the introduction of the trigger of final maturation of the follicles, the total efficiency of the oocyte-cumulus complexes obtained in transvaginal puncture, degree of maturity of oocytes, the frequency of degenerative changes in the egg, the percentage of fertilization, the crushing of embryos, the blastocyst yield.

Conclusions. Pregravid therapy with a combination of inositol and vitamin D, increases the sensitivity of ovaries to stimulation and improves the results of assisted reproductive technologies. Conducting surgical 
interventions in patients with genital endometriosis of grade I and II severity is recommended after stimulation of supraovulation in ART programs.

KEY WORDS: endometriosis; infertility; antioxidant therapy; assisted reproductive technologies.

Рукопис надійшов до редакції 23.10.2018 p.

\section{Відомості про авторів:}

Хміль Стефан Володимирович - професор кафедри акушерства та гінекології № 1 ДВН3 «Тернопільський державний медичний університет імені І. Я. Горбачевського МОЗ України» заслужений діяч науки і техніки України, професор, доктор медичних наук. Директор Медичного центру «Клініка професора С. Хміля».

Кулик Ірина Ігорівна - завідувач відділення репродуктології Медичного центру «Клініка профресора С. Хміля», лікар акушер-гінеколог, репродуктолог.

Микула Руслана Петрівна - ембріолог Медичного центру «Клініка профресора С. Хміля»; тел.: +38(097) 620-97-86. 